\title{
Kinship Terminology: Problems in Some English-Tshivenda Bilingual Dictionaries
}

\author{
Munzhedzi James Mafela, Department of African Languages, University \\ of South Africa (UNISA), Pretoria, Republic of South Africa \\ (mafelmj@unisa.ac.za)
}

\begin{abstract}
With the introduction of a new political dispensation in South Africa, bilingual dictionaries have become a necessary part of daily life. The main function of a bilingual dictionary is to provide one or more equivalents in the target language for the entry words in the source language. Not all bilingual dictionaries realize this objective satisfactorily, Tshivenda bilingual dictionaries included. Some bilingual dictionaries in Tshivenda provide one equivalent instead of all equivalents associated with the entry word of the source language, especially if Tshivenda is the target language. Not providing all equivalents renders a bilingual dictionary inadequate, because users do not always find what they look for. By focusing on kinship terms in some English-Tshivenda bilingual dictionaries, this article discusses examples of inadequate treatment. The article further advocates the inclusion of all possible equivalents under such entry words.
\end{abstract}

Keywords: BILINGUAL DICTIONARY, CROSS-RELATIONSHIP, DICTIONARY USER, EQUIVALENT, INDIGENOUS LANGUAGE, KINSHIP TERMINOLOGY, ORTHO-RELATIONSHIP, SOURCE LANGUAGE, LEXICAL UNIT, LEXICOGRAPHER, RELATIVES, TARGET LANGUAGE, TRANSLATION

Opsomming: Verwantskapsterminologie: Probleme in sommige EngelsTshivenda tweetalige woordeboeke. Met die invoering van 'n nuwe politieke bedeling in Suid-Afrika het tweetalige woordeboeke 'n noodsaaklike deel van die daaglikse lewe geword. Die hooffunksie van 'n tweetalige woordeboek is om een of meer ekwivalente in die doeltaal vir die trefwoorde in die brontaal te verskaf. Nie alle tweetalige woordeboeke verwesenlik hierdie doel bevredigend nie, Tshivenda tweetalige woordeboeke ingesluit. Sommige tweetalige woordeboeke in Tshivenda verskaf een ekwivalent in plaas van al die ekwivalente wat in verband staan met die trefwoord van die brontaal, veral as Tshivenda die doeltaal is. Deur nie alle ekwivalente te verskaf nie maak ' $n$ tweetalige woordeboek ontoereikend omdat gebruikers nie altyd kry wat hulle soek nie. Deur op verwantskapsterme in sommige Engels-Tshivenda tweetalige woordeboeke te fokus, bespreek hierdie artikel voorbeelde van onvoldoende behandeling. Verder bepleit die artikel die insluiting van alle moontlike ekwivalente onder sulke trefwoorde.

Sleutelwoorde: BRONTAAL, DOELTAAL, EKWIVALENT, INHEEMSE TAAL, KRUISVERWANTSKAP, LEKSIKALE EENHEID, LEKSIKOGRAAF, ORTOVERWANTSKAP, TWEETALIGE WOORDEBOEK, VERTALING, VERWANTE, VERWANTSKAPSTERMINOLOGIE, WOORDEBOEKGEBRUIKER 


\section{Introduction}

A bilingual dictionary deals with the translation of entry words from one language into another language. Equivalents of the target language are provided for the entries of the source language. According to Zgusta (1971: 294), the aim of a bilingual dictionary is to co-ordinate the lexical units of one language with those units of another language which are equivalent in their lexical meaning. Whereas the basic function of a dictionary is to define words, the major task of a bilingual lexicographer is to find appropriate equivalents in the target language for units of the source language (Al-Kasimi 1983: 58). People daily need bilingual dictionaries for their translation problems and queries, especially those who learn other languages. Bilingual dictionaries are the most used in the new South Africa. Translation from languages such as English and Afrikaans into indigenous languages plays an important role, because all indigenous languages, alongside English and Afrikaans, are now recognized as official languages. People are entitled to receive information through their principal languages, hence the importance of translation. Bilingual dictionaries are therefore indispensable in the translation process.

Kinship terminology involves terms people in a society use to classify their relatives. It can therefore be defined as the system of names applied to categories of kin standing in relationship to one another (McHenry 1992a: 881). Stone (2000: 5) sees kinship as relationships between persons based on descent or marriage. However, kinship terminology varies from one language to another. In some instances, providing the actual meaning and correct equivalents of kinship terms is difficult. Languages differ in the way they express certain meanings. The target language may make more or fewer distinctions in meaning than the source language (Baker 1992: 22). In certain cases, the difference in the manner languages convey meaning is caused by cultural differences between the source language and the target language. McHenry (1992b: 282) stresses that "the finding of exact equivalents is more difficult than is commonly realized, because every language slices up the world in its own particular way". This is also expressed in kinship terminology. Stone (2000) says societies vary in the extent to which kinship connections form the basis of their social, economic and political structures. There may therefore not be a correspondence in terms. According to Al-Kasimi (1983: 63), two related items in two different languages may not cover the same semantic range.

In many instances, a kinship term in English has two or more equivalents in Tshivenda. Although Tshivenda has two or more equivalents for one kinship term in English, these are not reflected in some English-Tshivenda bilingual dictionaries. Only one equivalent is given, which may mislead a bilingual dictionary user, because all the meanings are not covered. As stated above, every culture has relations of kinship and has a system of kinship classification. The fundamental distinction running through Tshivenda kinship is that between ortho-relationship (a relationship between those of the same sex) and cross-rela- 
tionship (a relationship between those of opposite sexes) (Van Warmelo 1904: 108). The purpose of this article is to highlight the lack of providing all the Tshivenda equivalents with regard to kinship terms in some English-Tshivenda bilingual dictionaries, and further to advocate that all the meanings of kinship terms be included as Tshivenda equivalents. The dictionaries from which illustrative material is drawn are the English-Venda Vocabulary by L.T. Marole and the Improved Trilingual Dictionary: Venda-Afrikaans-English by P.J. Wentzel and T.W. Muloiwa. The Improved Trilingual Dictionary: Venda-Afrikaans-English comprises three sections, namely, Venda-Afrikaans-English, Afrikaans-Venda, and English-Venda. In this discussion, the focus will be on the English-Venda section. Although these dictionaries are not as comprehensive as would be expected, they are better structured than the other EnglishTshivenda bilingual dictionaries.

\section{Equivalence and kinship terms in English-Tshivenda bilingual dic- tionaries}

Prinsloo and De Schryver (2002: 162) define equivalent as a word or phrase in one language which corresponds in meaning to a word or phrase in another language. The issue of providing Tshivenda equivalents of the English kinship terms is one of the core problems in English-Tshivenda bilingual dictionaries. In English, the term aunt means the sister of one's mother or father, and the wife of one's uncle. However, in Tshivenda, aunt is used to denote a sister of one's father only, and she is called makhadzi. A sister of one's mother is called mmane (little mother), if younger than one's mother, and mmemuhulu (big mother), if older than one's mother. The adjectives little and big have been used to define the type of mother, because there are no English equivalents for mmane and mmemuhulu respectively. The wife of one's uncle is called makhulu. For the English kinship term aunt in this case, Tshivenda has three equivalents, i.e. makhadzi, mmane and mmemuhulu. In Marole (1954), only one equivalent is provided, i.e.

$$
\text { aunt - (n.) makhadzi, khaladzi ya khotsi }
$$

The equivalent provided in the entry is makhadzi, which is further defined as khaladzi ya khotsi (sister of one's father). The other meanings, mmane and mmemuhulu, have been omitted. This means that aunts from the side of the mother are not given. The failure of the lexicographer to provide the other two equivalents in his definition of the entry word aunt, may lead to dictionary users acquiring wrong meanings if they are looking for mmane and mmemuhulu. In the Tshivenda system, a person's mother and mother's sisters are called by one term and the father's sisters by another. One's mother and mother's sisters are called mme (mother), while the father's sisters are called makhadzi. The same applies to the kinship term uncle. In English, uncle means brother of one's father or mother, and an aunt's husband (Allen 1990). Scheffler and Lounsbury (1971: 
7) say: "The English kinship term 'uncle' is polysemic; it may be used to designate the class of kinsmen defined as 'the brother of either of one's parents' or to designate one of two different but related classes of kinsmen, namely (1) the husbands of 'aunts' in which case we may speak more precisely of 'uncles by marriage' and (2) the brothers of grandparents, rather than of parents, in which case we may speak more precisely of 'great uncles'." Polysemy refers to instances where the same word may have a set of different meanings. In Tshivenda, the use of uncle is restricted to the brother of one's mother and is referred to as malume. The brother of one's father is called khotsimunene (little father), if younger than one's father, and khotsimuhulu (big father), if older than one's father. A person distinguishes between the brothers of his/her father as khotsimuhulu or khotsimunene, depending on whether they are older or younger than one's father. In its kinship system, Tshivenda makes a distinction with regard to seniority. Brothers of a person's mother are called malume irrespective of relative age or status (Mönnig 1978: 241). As Hammel (1966: 7) says: "The relationship of seniority and juniority are, in this analysis, more important than the raw data would immediately indicate." The distinction by relative age is also applied to the sisters of one's mother, i.e. mmane and mmemuhulu. Marole (1954) provides one equivalent, malume, for the English kinship term uncle.

$$
\text { uncle - (n.) malume }
$$

In contrast to the equivalent makhadzi, there is no further definition. To make the meaning of malume clear to the dictionary user, the lexicographer should further have added khaladzi ya mme (brother of one's mother). Tshivenda indicates father's brother by one term, and mother's brother by a different one. The equivalents omitted in the definition are khotsimunene and khotsimuhulu. Uncles from the side of the father have been excluded. The exclusion of other equivalents may lead to a wrong choice of meaning of the English kinship term uncle. If the lexicographer had provided all the Tshivenda equivalents of the entry word uncle, he would have given dictionary users a wide scope of the meanings in the target language, from which to choose.

In English, brother designates "a male as he is related to other children of his parents" (Guralnik 1981). Tshivenda has three equivalents for the term brother, i.e. mukomana (elder brother), murathu (younger brother), and khaladzi (girl's male sibling). For khaladzi, age and gender are irrelevant. In Marole (1954), the equivalent of brother is given as follows:

$$
\text { brother - (n.) murathu }
$$

The equivalent only refers to one meaning of brother, namely murathu (little brother). Out of the three possible equivalents, only one has therefore been provided. The other two, mukomana (big brother) and khaladzi (girl's male sibling) have been omitted. As indicated above, leaving out other equivalents will lead dictionary users to make a wrong choice if the equivalent murathu is not required. The same applies to the English kinship term sister. Guralnik (1981) 
defines sister as "a female as she is related to other children of her parents". For the English sister, Tshivenda has three equivalents, i.e. mukomana (elder sister), murathu (younger sister) and khaladzi (boy's female sibling). As in the case of the kinship term brother, the emphasis is on seniority. Larson (1984: 83) writes: "There are languages in which one cannot simply say brother because there may be two or more words to choose from." For both brother and sister, Tshivenda has three equivalents each. In Marole (1954), the Tshivenda equivalent of sister is provided as follows:

sister - (n.) khaladzi wa tshisadzini

The equivalent in Tshivenda is khaladzi with a qualifying phrase wa tshisadzini (who is female). The other two equivalents, i.e. mukomana and murathu, have been omitted. Definitions of the terms brother and sister in the target language are therefore not complete without the other equivalents.

The provision of the Tshivenda equivalents for the kinship terms uncle, aunt, sister and brother in Wentzel and Muloiwa (1982) has been handled fairly well. All meanings entailed in each kinship term have been provided. Dictionary users do not encounter problems in choosing the equivalents. The definitions of the English terms appear as follows in Wentzel and Muloiwa (1982):

uncle: (mother's brother) malume (vho-); (father's elder brother) khotsimuhulu (vho-); (father's younger brother) khotsimunene (vho-)

aunt: (father's sister) makhadzi (vho-); (mother's elder sister) mmemuhulu (vho-); (mother's younger sister) mmane (vho-)

sister: (sister of male person) khaladzi; (younger sister of female person) murathu (vha-); (elder sister of female person) mukomana (vha-)

brother: (elder brother of male) mukomana (vha-); (younger brother of male) murathu (vha-); (brother of female person) khaladzi (dzi-)

The term khaladzi is used for a male or female sibling, irrespective of age, whereas the terms murathu and mukomana are used for a younger male or female sibling of the same sex and for an older male or female sibling of the same sex respectively. The prefixes vho-, vha- and $d z i$ - in the definitions denote the plural forms of the Tshivenda kinship terms.

In English, children of one's father's or mother's brothers or sisters are one's cousins. This is not so in Tshivenda, because they are all considered one's brothers or one's sisters. According to Mönnig (1978: 237), the children of a father's brother are treated in much the same way as are a person's male siblings. In English, cousin means the son or daughter of one's uncle (including one's father's younger and elder brothers) or aunt (including one's mother's younger and elder sisters). In Tshivenda, the meaning of cousin is restricted to the children of one's father's sister and those of one's mother's brother. They are all referred to as muzwala. In his definition of the kinship term cousin, Marole 
(1954) provides the equivalent as:

$$
\text { cousin - (n.) muzwala }
$$

Equivalents pertaining to children of the father's brother and those of the mother's sister are not provided, because in Tshivenda they are not considered as cousins, but as mukomana, murathu and khaladzi. A person learning Tshivenda will never know whether some cousins in Tshivenda are called murathu or mukomana or khaladzi, if the equivalents are not reflected. The lexicographer should provide the other meanings of cousin, because there is no other place where the dictionary user will find them, especially if he/she is learning Tshivenda. Wentzel and Muloiwa (1982) also provide the equivalent of the English kinship term cousin as muzwala, presenting it as follows:

cousin - (cross-cousin) muzwala (vha-)

As in Marole (1954), only cousins of cross-relationship are mentioned here. However, Marole does not indicate in his definition whether the term cousin involves cross-relationship or ortho-relationship. In both dictionaries, nothing is mentioned about cousins of ortho-relationship. If the dictionary user is looking for a cousin of ortho-relationship, he/she would be left in the lurch, because there is no way of finding it if not defined under the entry word cousin. In this case, a bilingual dictionary does not fulfil its purpose.

On the other hand, the kinship term niece means the daughter of one's brother or sister, and the daughter of one's brother-in-law or sister-in-law. In Tshivenda, niece denotes one's brother's daughter, if one is female, and one's sister's daughter, if one is male. If one is female, the daughter of one's brotherin-law is one's daughter, and if one is male, the daughter of one's sister-in-law is also one's daughter. The equivalent of niece in Marole (1954) is provided as:

niece - (n-) muduhulu wa musidzana

In this definition, the equivalent is given as muduhulu accompanied by a qualifying phrase wa musidzana which means "who is a girl". The lexicographer did this, because he knows that there is more than one equivalent for niece in Tshivenda. However, he did not provide the other equivalents, i.e. one's brother's daughter, if one is male, and one's sister's daughter, if one is female, because he is aware that in Tshivenda they are all called one's daughters. Furthermore, muduhulu does not take gender in consideration, both nephew and niece are called muduhulu in Tshivenda. For the lexicographer to help a dictionary user to discriminate the meanings, all senses must be reflected under the entry word niece. Wentzel and Muloiwa (1982) give the equivalents of niece as follows:

niece - muduhulu (vha-); rwana (vha-)

The lexicographers have provided two equivalents, i.e. muduhulu and ṅwana. 
Each of the Tshivenda terms muduhulu and riwana has more than one meaning. The lexicographers should have discriminated the meanings of both terms to help dictionary users to make the correct choice of equivalents. For example, in Tshivenda riwana means one's own child, one's brother's child, if one is male, one's sister's child, if one is female, one's sister-in-law's child, if one is male, and one's brother-in-law's child, if one is female. In Tshivenda, the meanings of muduhulu, the equivalent of niece, are one's sister's child, if one is male, and one's brother's child, if one is female. It does not, however, denote one's own child. The equivalents provided should therefore read as follows:

niece - muduhulu (vha-) granddaughter; one's sister's daughter - if one is male; one's brother's daughter - if one is female

- nwana (vha-) one's own child; one's brother's child - if one is male; one's sister's child - if one is female; one's sister-in-law's child - if one is male; one's brother-in-law's child — if one is female

The same holds for nephew, which is not included in Marole's bilingual dictionary. Wentzel and Muloiwa (1982) translate nephew as:

nephew: muduhulu (vha-); riwana (vha-)

The Tshivenda equivalents of the English term are the same as those of niece. As with niece, the equivalents are muduhulu and niwana. The lexicographers did not discriminate the meanings encompassed by the equivalents muduhulu and niwana. As a result, dictionary users can encounter problems regarding obtaining the correct equivalent for which they are looking. For the purpose of including all the meanings of the equivalents, the definition of the entry word should look as follows:

nephew - muduhulu (vha-) grandson, one's sister's son - if one is male; one's brother's son - if one is female

- nwana (vha-) one's own child; one's brother's child - if one is male; one's sister's child - if one is female; one's sister-in-law's child - if one is male; one's brother-in-law's child — if one is female; one's son-in-law

In contrast to English, the Tshivenda equivalents of niece and nephew, which are muduhulu and riwana, are not affected by gender. While in English the female is called niece and the male is called nephew, in Tshivenda both the female and the male are referred to as muduhulu and iwana. Unlike the other kinship terms discussed above, meaning discrimination plays an important role in the definitions of the Tshivenda equivalents muduhulu and niwana, because each equivalent encompasses more than one meaning. The absence of meaning discrimination will confuse dictionary users so that they might choose wrong equivalents. 


\section{Conclusion}

The above exposition has shown that in the discussed English-Tshivenda bilingual dictionaries, the lexicographers did not achieve the objective of a bilingual dictionary, i.e. that of co-ordinating the lexical units of one language with those units of another language which are equivalent in their lexical meaning. The lexicographers failed to provide all possible Tshivenda kinship equivalents for the relevant English entry words. As a result, these bilingual dictionaries are not user-friendly. The discussion has also revealed that kinship terminology in English and Tshivenda differs, because kinship relationships are closely related to the speaker's experience. As Mbananga (2003: 115) writes: "The languages of different communities in South Africa are part of cultural diversity. Language has an intrinsic value closely connected with the cultural identity, knowledge and understanding." In showing the differences of kinship relation between English and African languages, Mandela (1995: 10) says: "In African culture, the sons and daughters of one's aunts and uncles are considered brothers and sisters, not cousins. We do not make the same distinctions among relations practised by Whites. We have no half-brothers or half-sisters. My mother's sister is my mother; my uncle's son is my brother; my brother's child is my son, my daughter." Bilingual dictionary lexicographers must always keep in mind that there will be no one-to-one correspondence between words across languages, because of cultural differences. Therefore, there is a need for lexicographers to acquaint themselves with the culture of the target language to provide all the possible equivalents.

\section{References}

\section{Dictionaries}

Allen, R.E. (Ed.). 1990. The Concise Oxford Dictionary of Current English. New York: Oxford University Press.

Guralnik, D.B. (Ed.). 1981. Webster's New World Dictionary of the American Language. Student Edition. Englewood Cliffs, New Jersey: Simon and Schuster.

Marole, L.T. 1954. English-Venda Vocabulary. Sibasa: Marole Book Depot.

Wentzel, P.J. and T.W. Muloiwa. 1982. Improved Trilingual Dictionary: Venda-Afrikaans-English. Pretoria: University of South Africa.

\section{Other Sources}

Al-Kasimi, A.M. 1983. Linguistics and Bilingual Dictionaries. Leiden: E.J. Brill.

Baker, M. 1992. In Other Words: A Coursebook on Translation. London: Routledge.

Hammel, E.A. 1966. A Factor Theory for Aruta Kinship Terminology: Anthropological Records, Volume 24. Berkeley/Los Angeles: California Press. 
Larson, M.L. 1984. Meaning-based Translation: A Guide to Cross-language Equivalence. New York: University Press of America.

Mandela, N.R. 1995. Long Walk to Freedom: The Autobiography of Nelson Mandela. London: Routledge.

Mbananga, N. 2003. Multi-cultural and Multi-lingual Society: A Challenge for e-Health in South Africa. De Schryver, Gilles-Maurice (Ed.). 2003. Sixth International TAMA Conference: Conference Proceedings. Pretoria: (SF)2 Press.

McHenry, R. (Ed.). 1992a. The New Encyclopaedia Britannica. Volume 6. Chicago: Encyclopaedia Britannica Inc.

McHenry, R. (Ed.). 1992b. New Encyclopaedia Britannica. Volume 18. Chicago: Encyclopaedia Britannica Inc.

Mönnig, H.O. 1978. The Pedi. Pretoria: J.L. van Schaik.

Prinsloo, D.J. and Gilles-Maurice de Schryver. 2002. Reversing an African-language Lexicon: The Northern Sotho Terminology and Orthography No. 4 as a Case in Point. South African Journal of African Languages 22(2): 161-185.

Scheffler, H.W. and F.G. Lounsbury. 1971. A Study in Structural Semantics: The Siriono Kinship System. Englewood Cliffs, New Jersey: Prentice-Hall Inc.

Stone, L. 2000. Kinship and Gender: An Introduction. Second Edition. Colorado: Westview.

Van Warmelo, N.J. 1904. Kinship Terminology of the South African Bantu. Pretoria: Government Printers.

Zgusta, L. 1971. Manual of Lexicography. The Hague/Paris: Mouton. 